\title{
The New Great Game
}


Studies of the Walter H. Shorenstein Asia-Pacific Research Center

Andrew G. Walder, General Editor

The Walter H. Shorenstein Asia-Pacific Research Center in the Freeman Spogli Institute for International Studies at Stanford University sponsors interdisciplinary research on the politics, economies, and societies of contemporary Asia. This monograph series features academic and policy-oriented research by Stanford faculty and other scholars associated with the Center. 
ALSO PUBLISHED IN THE

SHORENSTEIN ASIA-PACIFIC RESEARCH CENTER SERIES

Rebranding Islam: Piety, Prosperity, and a Self-Help Guru

James Bourk Hoesterey (2015)

Global Talent: Skilled Labor as Social Capital in Korea

Gi-Wook Shin and Joon Nak Choi (2015)

Failed Democratization in Prewar Japan: Breakdown of a Hybrid Regime Harukata Takenaka (2014)

New Challenges for Maturing Democracies in Korea and Taiwan

Edited by Larry Diamond and Gi-Wook Shin (20I4)

Spending Without Taxation: FILP and the Politics of Public Finance in Japan Gene Park (20II)

The Institutional Imperative: The Politics of Equitable Development in

Southeast Asia

Erik Martinez Kuhonta (20II)

One Alliance, Two Lenses: U.S.-Korea Relations in a New Era

Gi-Wook Shin (2010)

Collective Resistance in China: Why Popular Protests Succeed or Fail

Yongshun Cai (2010)

The Chinese Cultural Revolution as History

Edited by Joseph W. Esherick, Paul G. Pickowicz, and

Andrew G. Walder (2006)

Ethnic Nationalism in Korea: Genealogy, Politics, and Legacy

Gi-Wook Shin (2006)

Prospects for Peace in South Asia

Edited by Rafiq Dossani and Henry S. Rowen (2005) 



\section{The New Great Game}

CHINA ANDSOUTH AND CENTRALASIA

I N THE ERA OF REFORM

Edited by Thomas Fingar

Stanford University Press

Stanford, California 
Stanford University Press

Stanford, California

(C) 2016 by the Board of Trustees of the Leland Stanford Junior University.

All rights reserved.

No part of this book may be reproduced or transmitted in any form or by any means, electronic or mechanical, including photocopying and recording, or in any information storage or retrieval system without the prior written permission of Stanford University Press.

Printed in the United States of America on acid-free, archival-quality paper

Library of Congress Cataloging-in-Publication Data

The new great game : China and South and Central Asia in the era of reform / edited by Thomas Fingar.

pages $\mathrm{cm}$ - (Studies of the Walter H. Shorenstein Asia-Pacific Research Center) Includes bibliographical references and index.

ISBN 978-0-8047-9604-o (cloth : alk. paper) — ISBN 978-o-8047-9763-4 (pbk. : alk. paper)

I. South Asia-Foreign relations-China. 2. China-Foreign relations-South Asia. 3. Asia, Central—Foreign relations—China. 4. China-Foreign relations-Asia, Central. 5. China-Foreign relations-1976- I. Fingar, Thomas, editor. II. Series: Studies of the Walter H. Shorenstein Asia-Pacific Research Center. DS34I.3.C5N47 2016 $327.51054-\mathrm{dc} 23$

ISBN 978-0-8047-9764-I (electronic)

Typeset by Newgen in II/I4 Garamond 